\section{The Autoimmune Diseases: Pathogenesis and Prophylaxis}

\section{Adams DD* and Adams TW}

Faculty of Medicine, University of Otago, Dunedin, New Zealand

\section{Introduction}

Epidemics of infectious diseases, such as the great plague of London, partly erased by the great fire, were of mysterious origin until Louis Pasteur (Figure 1) introduced the correct Germ Theory of Disease [1], in opposition to the prevailing theory that life was generated spontaneously in decaying organic matter. Lionel Whitby [2] initiated brilliant study of medical bacteriology, which was carried on by others as described by Baron [3], producing amazingly detailed knowledge of Microbiology.

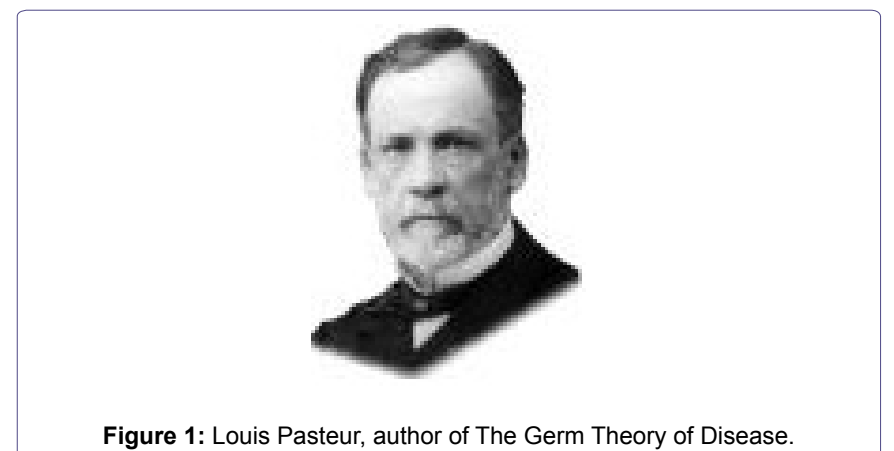

\section{The Immunity System}

This exists for defence against infectious diseases, as well described by Arthur Silverstein in William Paul's classic textbook [4], the description of Nobel Prize highlights summarising major advances well.

\section{Autoimmune Disease}

The steps involved in the discovery of the existence and the pathogenesis of the autoimmune diseases are shown in Table 1. As antibodies that fitted specific germs had been discovered, it was natural to think that they were built on a template of antigen. However, Miescher discovered the structure of DNA (Deoxyribonucleic Acid). Then Watson and Crick [5,6] discovered that the order of four bases in a very long double helix provides the genetic code for man and other creatures. Armed with this revolutionary knowledge, Niels Jerne [7] realised that cells are factories that can swiftly convert DNA to RNA to polypeptide, and proposed the Selection Theory,

*Corresponding author: Adams DD, Faculty of Medicine, University of Otago, Dunedin, New Zealand, Tel: +64 34877989; E-mail: duncan.adams@xtra.co.nz

Citation: Adams DD, Adams TW (2015) The Autoimmune Diseases: Pathogenesis and Prophylaxis. J Clin Immunol Immunother 2: 005.

Received: October 02, 2014; Accepted: January 06, 2015; Published: January 20, 2015 postulating that antibodies are preformed in myriad diversity, awaiting contact with an antigen that fits (Figure 2). Macfarlane Burnet capped this by realizing that it is not antibodies that are selected, but the cells that make them, and that these cells are the lymphocytes, previously thought of as passive spectators of infection (Figure 3). On encountering a complementary antigen, lymphocytes change from having scant cytoplasm to being a blast cell, with copious cytoplasm, able to replicate to form new cells. Burnet realized that the unit of immune specificity is the immunological clone, a subset of lymphocytes with identical receptors for antigen, hence his Clonal Selection Theory of acquired immunity [8].

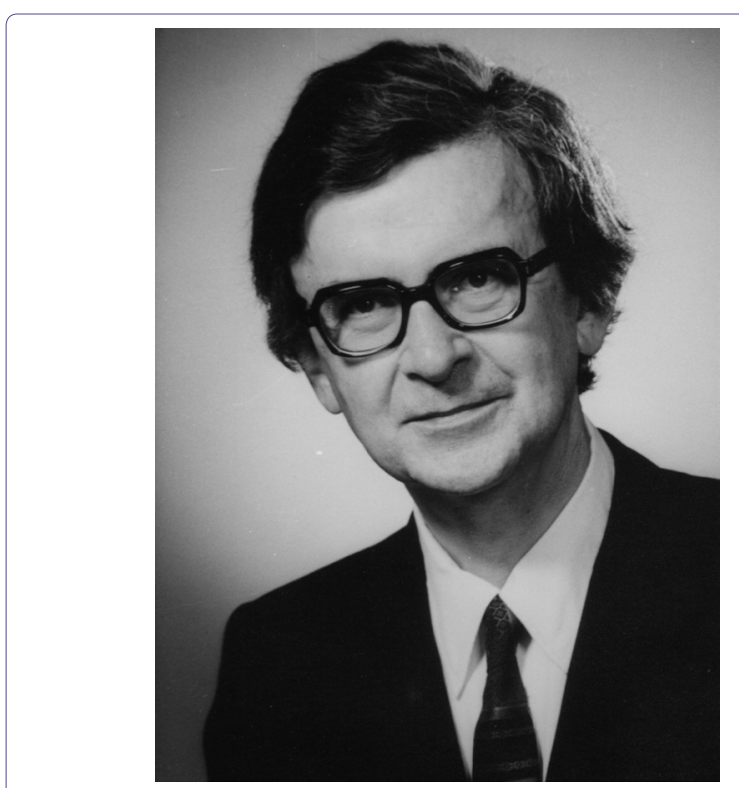

Figure 2: Niels Jerne, author of the Selection Theory of the Immune Response.

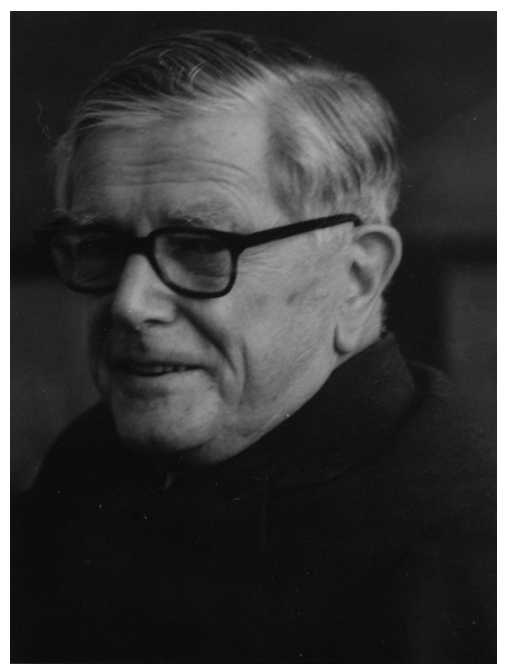

Figure 3: Macfarlane Burnet, author of the Forbidden Clone Theory of Autoimmune Disease. 


\begin{tabular}{|c|c|}
\hline \multicolumn{2}{|c|}{$\begin{array}{l}\text { Mutations in the } V \text { genes of multiplying lymphocytes are the cause of the autoimmune } \\
\text { diseases }\end{array}$} \\
\hline Haurowitz & $\begin{array}{l}\text { Template theory of antibody formation. Antibodies are } \\
\text { built on a template of antigen. Wrong. }\end{array}$ \\
\hline Watson and Crick & $\begin{array}{l}\text { Cells are factories able to make myriad different } \\
\text { polypeptides by transcribing DNA chains to RNA chains } \\
\text { and translating them to polypeptide chains }\end{array}$ \\
\hline Jerne & $\begin{array}{l}\text { The Selection Theory of antibody formation: Antibodies } \\
\text { are pre-formed in myriad diversity awaiting selection by } \\
\text { an antigen that fits. }\end{array}$ \\
\hline Burnet [8] & $\begin{array}{l}\text { The Clonal Selection Theory: It is not antibodies but } \\
\text { their parent lymphocytes that are selected. The unit of } \\
\text { immune specificity is the lymphocyte clone, a subset of } \\
\text { lymphocytes with identical receptors for antigen. }\end{array}$ \\
\hline \multicolumn{2}{|c|}{ Discovery of autoimmunity } \\
\hline Dameshek [9] & Autoimmune haemolytic anaemia. \\
\hline Freund [10] & $\begin{array}{l}\text { Autoimmune destruction of guinea pig testes using } \\
\text { adjuvants. }\end{array}$ \\
\hline Adams and Purves [11] & Thyrotoxicosis \\
\hline Witebsky and Rose [12] & Autoimmune thyroiditis \\
\hline Doniach and Roitt [13] & Thyroid autoimmunity. \\
\hline Porter [14] & $\begin{array}{l}\text { Variable region }(\mathrm{V}) \text { genes code for antigen receptors on } \\
\text { lymphocytes and their antibodies. }\end{array}$ \\
\hline Burnet [15] & $\begin{array}{l}\text { The Forbidden Clone Theory: The Forbidden Clones } \\
\text { that cause autoimmune disease arise by somatic gene } \\
\text { mutations in the } \vee \text { genes of multiplying lymphocytes. }\end{array}$ \\
\hline Knight et al., [16] & $\begin{array}{l}\text { Thyroid-Stimulating autoantibodies (TSab) in individual } \\
\text { patients contain only one type of light chain, showing } \\
\text { origin from mutation in a single lymphocyte }\end{array}$ \\
\hline Knight and Adams [17] & $\begin{array}{l}\text { Absence of allotypic variation in the autoantigen for } \\
\text { thyroid stimulating autoantibodies }\end{array}$ \\
\hline Ben-Nun et al., [18] & $\begin{array}{l}\text { Isolation of antigen specific } T \text { cell lines capable of } \\
\text { mediating autoimmune encephalomyelitis. }\end{array}$ \\
\hline Cheynier et al., [19] & Somatic mutation occurs in T lymphocyte V genes. \\
\hline Sherwin [20] & $\begin{array}{l}\text { Type } 1 \text { diabetes is caused by specific destruction of } \\
\text { pancreatic islet } \beta \text { cells by cytotoxic T cell forbidden clones }\end{array}$ \\
\hline Adams [21] & $\begin{array}{l}\text { Diabetic retinopathy: Evidence that cytotoxic } T \text { cell } \\
\text { forbidden clones cause diabetic retinopathy by selectively } \\
\text { destroying pericytes. }\end{array}$ \\
\hline
\end{tabular}

Table 1: The Jerne-Burnet Forbidden Clone Theory of Autoimmune Disease.

\section{Discovery of Autoimmunity}

This happened in 1938 when Dameshek and Schwartz [9], Haematologists, discovered autoimmune haemolytic anaemia. However, this was ignored as an oddity. Then in 1953, Freund et al., [10] produced autoimmune destruction of the testes in guinea pigs by immunising them with testicular tissue and adjuvants that prolonged the antigenic stimulus long enough for the necessary somatic mutations to occur in the responding lymphocytes. Similarly using adjuvants, Witebsky et al., [12] with a JAMA paper, put autoimmunity on the medical map by producing autoimmune thyroiditis in rabbits.

In the same year, Deborah Doniach and Ivan Roitt [13] showed that Hashimoto's disease of the thyroid is caused by autoimmunity. Then Adams and Purves discovered the Long-Acting Thyroid Stimulator (LATS) that eventually proved to be the thyroidstimulatingautoantibodiesthatcausethyrotoxicosis[11].McKenzie[22] confirmed the discovery of LATS, adapting the guinea pig assay to the mouse, which was advantageous.

\section{Burnet's Forbidden Clone Theory}

Being a Bacteriologist, used to counting mutation rates in bacteria growing on blood agar plates, Burnet realised that multiplying lymphocytes will mutate similarly, hence his Forbidden Clone Theory of autoimmune disease [15]. This postulates that somatic mutations in the $\mathrm{V}$ (Variable region) genes of multiplying lymphocytes produce the aptly named forbidden clones of lymphocytes that cause the autoimmune diseases by reacting with a host antigen instead of a microbial one.

\section{Confirmation of the Forbidden Clone Theory}

This is shown in Table 1, which reports John Knight's demonstration that Thyroid-Stimulating antibodies (TSab) in individual patients contain only one type of light chain, indicating origin from a single lymphocyte [16]. Additionally, Allison Knight, Cague and Adams set up a precise system for measuring LATS protector [23], which was used to show absence of allotypic variation in the autoantigen for thyroid stimulating autoantibodies [17].

\section{LATS Protector}

Trying to make the LATS assay more specific for small responses, Adams and Kennedy made use of Kriss' discovery [24] that thyroid extracts will neutralize LATS when incubated with it. However, they found that LATS from different patients showed wide variation in its susceptibility to neutralization. Suspecting an interfering substance, they found that LATS-negative sera from patients with Graves' disease contained another thyroid autoantibody, which protected LATS from neutralization by competing with it for reaction with the thyroid antigen. Hence, the name LATS protector. The new antibody had no stimulating effect in the mouse bioassay. Baffled, we published this finding [25] and soon had the good fortune to receive the following letter from Deborah Doniach.

\section{A Letter from Deborah Doniach}

London, May $5^{\text {th }}, 1967$.

\section{Dear Duncan,}

I wonder why you assume that the new LATS blocking antibody is not active in vivo? It could be more species specific and therefore not show up in the mouse test, yet still have stimulating properties on the human thyroid.

Best wishes,

Deborah Doniach.

\section{LATS Protector, The Specific Human Thyroid Stimulator}

Ivan Roitt was behind this brilliant interpretation, which was entirely logical, as the neutralization was done with human thyroid extracts and the test for activity was performed in the mouse. When mouse thyroid extracts were used, LATS protector disappeared [26]. For final confirmation of the human thyroid-stimulating activity of LATS protector, it was necessary to round up half a dozen courageous Otago Medical School academics prepared to make themselves bioassay animals for LATS protector. This experiment, illustrated in Figure 4, showed that LATS protector does stimulate the human thyroid [27].

A control infusion of normal plasma has had no effect on the slowly rising blood ${ }^{125} \mathrm{I}$ level, but the LATSP infusion has caused a prominent and significant rise, indicating the occurrence of thyroid stimulation [27]. 


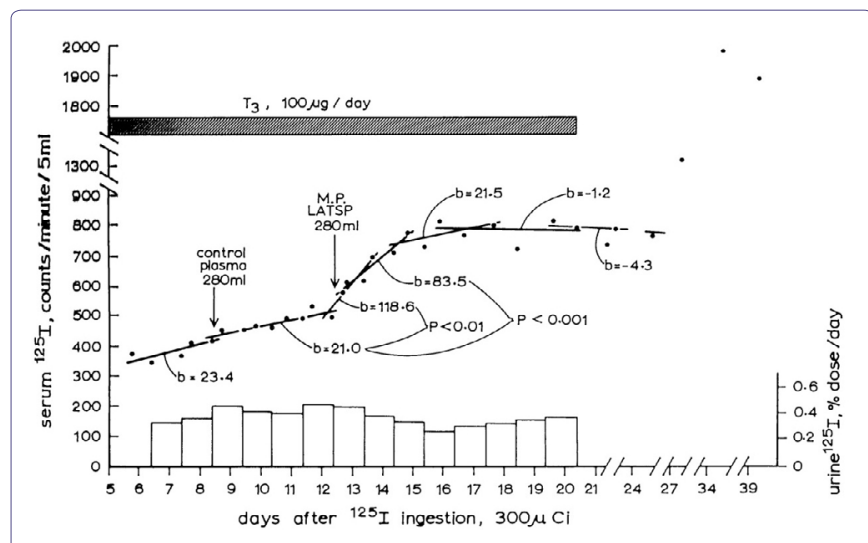

Figure 4: The effect of infusion of LATS Protector (LATSP) into a human volunteer.

With RDH Stewart and TH Kennedy, Adams showed LATS protector to be present in $90 \%$ of cases of untreated Graves' disease, including all the severe and moderately severe and moderately severe ones. Furthermore, there was a highly significant correlation between a patient's LATS protector level and her/his thyroid uptake of ${ }^{131} \mathrm{I}[28]$.

Figure 5 illustrates the pathogenesis of Graves' disease. It originates from a forbidden clone of lymphocytes, which have developed into plasma cells, able to secrete large amounts of Thyroid-Stimulating autoantibodies (TSaab). These stimulate the thyroid gland, causing thyroid hyperplasia and secretion of excessive amounts of thyroid hormone $\left(\mathrm{T}_{4}\right.$ and $\left.\mathrm{T}_{3}\right)$, which increases the metabolic rate to cause thyrotoxicosis. The high thyroid hormone levels also inhibit the thyrotroph cells of the anterior pituitary gland, by negative feed-back, so TSH secretion ceases, as does response to thyrotrophin-releasing hormone from the hypothalamus.

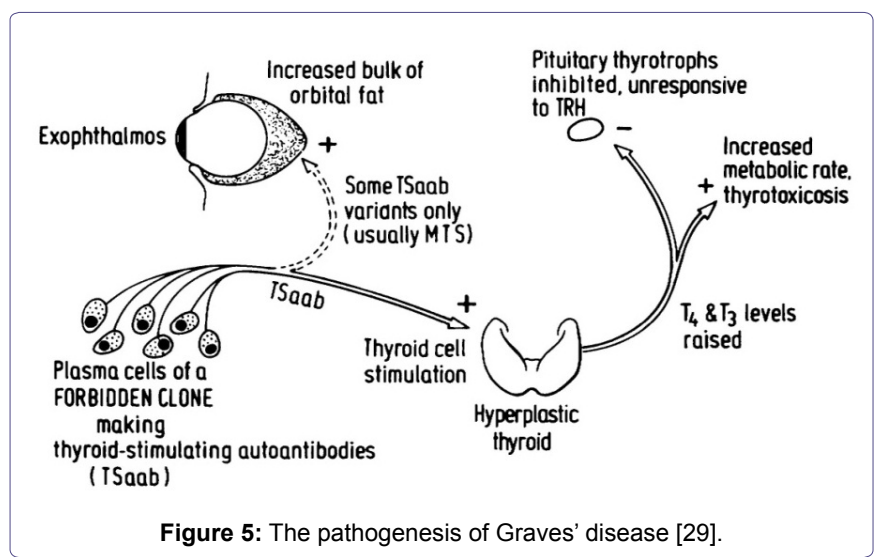

TSaab from forbidden clones of immunocytes stimulate the thyroid cells, causing overproduction of thyroid hormones $\mathrm{T}_{4}$ and $\mathrm{T}_{3}$ and the manifestations of thyrotoxicosis. The thyrotroph cells of the anterior pituitary are inhibited by the high blood thyroid hormone level, so TSH secretion ceases and response to TRH is absent. Some variants of TSaab react with receptors on fat cells in the orbit to cause exophthalmos from the bulk of adipocyte proliferation, demonstrated by Rundle and Pochin [30].

\section{Exophthalmos}

By ingenious post-mortem measurements, Rundle and Pochin [30] showed that in exophthalmos the component causing the increase in bulk of the extra-ocular orbital contents is fat, indicating that some TSaab variants, usually reactive with the mouse thyroid, cause proliferation of orbital adipose cells. Corticosteroid treatment is needed to inhibit this.

\section{Neonatal Thyrotoxicosis}

A quintessence of precision in the measurement of a pathogenic autoantibody was achieved by Susan Dirmikis et al., [31] who defined units of LATS protector, then showed that maternal LATS protector levels over 20 units $/ \mathrm{ml}$ invariably give rise to neonatal thyrotoxicosis in babies, whereas levels below 10 units/ml never do.

\section{Graves' Disease a Paradigm for Autoimmunity}

In 1986, at the University of Pisa, Professor Aldo Pinchera led an International Symposium on Thyroid Autoimmunity at which Graves' disease was presented as a paradigm for autoimmune disease [29].

\section{Discovery of the Structure of Antibody Molecules}

Serum, which is blood from which red cells and white cells have been removed, contain dissolved proteins, including the gamma globulins that are now called immunoglobulins because they are the antibodies. How could the atomic structure of such a great mixture of molecules be determined? Henry Kunkel solved this problem by using blood from patients with multiple myeloma, a cancer in which a lymphocyte cell becomes malignant, producing large amounts of a single antibody molecule. Kunkel's pupil, Gerald Edelman, broke the disulphide bonds holding antibodies together, revealing that each antibody molecule is comprised of four amino acid chains, two long ones and two short ones, the disulphide bonds holding them together to form a functional antibody. Rodney Porter [14] successfully split antibody molecules into their constituent amino acid chains, by using the weak proteolytic enzyme, papain. This produced three fragments, a Crystallizable Fragment, FC, the constant region, and two identical Fragments, FAB, each of which formed identical Antigen Binding sites [32] (Figure 6).

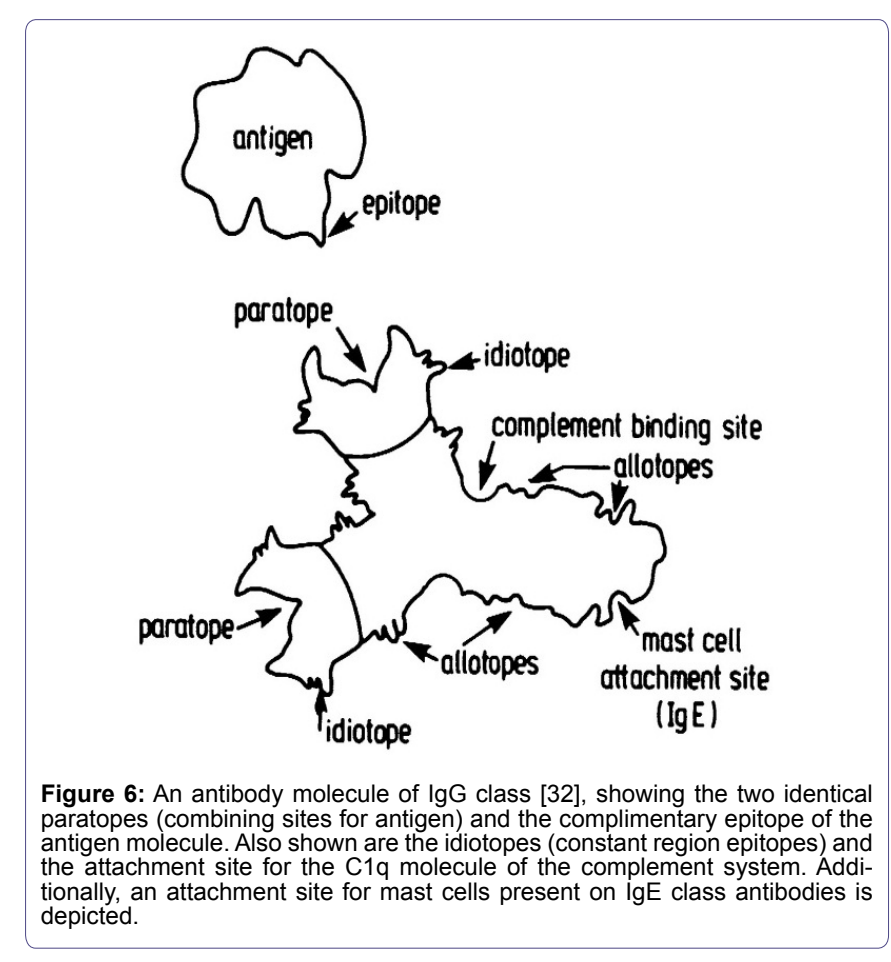




\section{Discovery of T and B Lymphocytes}

Some years after Haldane had discovered the histocompatibility system as described below, his nephew Avrion Mitchison [33], in a classic experiment, showed that rejection of allografts was not mediated by antibodies, but that lymphocyte cells are necessary, the rejection therefore being appropriately described as "cell mediated." This was the discovery of the cytotoxic $\mathrm{T}$ lymphocytes that bear the CD8 cluster of differentiation antigens surface marker and are essential for defence against virus infection. Mitchison also discovered the helper T lymphocytes that bear the CD4 surface marker and are necessary for firing off the cytokine secretions that mediate the cell cooperation involved in an immune attack on an invading microbe. The lymphocytes that act by secreting antibodies became known as B lymphocytes because of their origin from bone marrow, whereas $\mathrm{T}$ lymphocytes are named for their origin from the thymus.

The end of Table 1 reports examples of diseases caused by $\mathrm{T}$ cell forbidden clones.

Sherwin's epic research on Type 1 diabetes [20,34], diabetic retinopathy $[21,35]$, evidence that $\mathrm{T}$ lymphocytes undergo somatic mutations similarly to B lymphocytes [19] and Ben-Nun's classic isolation of antigen-specific $\mathrm{T}$ cell lines capable of mediating autoimmune encephalomyelitis [18].

\section{Pathogenic forbidden clones}

Table 2 describes pathogenic forbidden clones already discovered and others awaiting discovery. They are all comprised of $\mathrm{B}$ lymphocytes or $\mathrm{T}$ lymphocytes and act by stimulating or blocking a cell receptor or destroying a cell type.

\section{The Histocompatibility System}

\section{Discovery by Haldane}

By the beginning of the 1900 s, cancer researchers, trying to prevent and cure cancer in people, realized it would be helpful to their studies to be able to keep tumours going beyond the death of the animal in which it arose. However, they found that transferred tumours often died. An exception occurred when Japanese waltzing mice were used [61]. These animals that had been bred by fanciers for generations, were popular because people were amused by their antics, whirling and head-tossing. This is now known to be due to an inner ear (vestibular apparatus) defect, caused by a gene that is recessive, leading fanciers to produce an inbred strain of mice with the defect always present. It was found that a carcinoma from one of these mice grew in all the waltzing mice to which it was transplanted, but not in any other mice. With the discovery of the immune system, making antibodies to attack invading germs, people suspected that it was the immune system that caused the transplanted tumours to die, by attacking antigens on the tumour. However, JBS Haldane [62] correctly postulated that the immune attack was directed at allo-

\begin{tabular}{|c|c|c|}
\hline Disease or disorder & Autoantigen & Cell type of the forbidden clone \\
\hline Graves' disease & TSH receptor [29] & B cell, plasma cell \\
\hline Myasthenia Gravis & Acetylcholine receptor [18] & B cell, plasma cell \\
\hline Goodpasture's disease & On glomerular and lung basement membrane [36] & B cell, plasma cell \\
\hline Pernicious anaemia & Intrinsic factor [37] & B cell, plasma cell \\
\hline Systemic lupus erythaematosis & An intracellular component made copiously available by cytolysis [38] & B cell, plasma cell \\
\hline Hypocomplementaemia & $\begin{array}{l}\text { Alternative pathway C } 3 \text { convertase "abnormally stabilised by C3 nephritic } \\
\text { factor [41] }\end{array}$ & B cell, plasma cell \\
\hline Haemolytic anaemia & Red cell surface component [42] & B cell, plasma cell \\
\hline Rheumatoid arthritis & Type X1 collagen [43] Calpastatin [44] & B cell, plasma cell \\
\hline Schizophrenia & A neuronal dopaminergic receptor $[45,46]$ & B cell, plasma cell \\
\hline Manic depressive & ?Another neuronal receptor & B cell, plasma cell \\
\hline Systemic scleroderma & ?Fibroblast receptor causing excessive collagen formation [47-49] & B cell, plasma cell \\
\hline Paget's disease & ?Osteoclast receptor causing bone resorption [50] & B cell, plasma cell \\
\hline Ankylosing spondylitis & Spinal column epithelium component [51] B cell or T cell & B cell, plasma cell \\
\hline Post-streptococcal glomerulonephritis & $\begin{array}{l}\text { ?Intracellular glomerular component exposed by nephritogenic strep toxin } \\
\text { [52] }\end{array}$ & ?B cell as Ig is in the lesion \\
\hline Rheumatic fever & Heart component cross-reactive with streptococci [53] & $\begin{array}{l}\text { ?T cell as the heart autoantibodies also occur } \\
\text { in uncomplicated strep infection }[54,55]\end{array}$ \\
\hline Diabetes Type 1 & Islet $\beta$ cell surface component & Cytotoxic T cell, CD8 $[20,33]$ \\
\hline Diabetic retinopathy & On vascular pericyte cells & Cytotoxic T cell, CD8 $[34,35]$ \\
\hline Autoimmune hepatitis? & Hepatocyte surface component & ?Cytotoxic T cell, CD [56] \\
\hline Addison's disease & ?Adrenocortical cell surface & ?Cytotoxic T cell component [57] \\
\hline \multicolumn{3}{|l|}{ Primary biliary cirrhosis } \\
\hline & ?Ductal cell surface component [58] & Cytotoxic T cell, CD8 \\
\hline
\end{tabular}

Table 2: Discovered pathogenic forbidden clones and others awaiting discovery. 
antigens, not tumour antigens. He predicted that antigenic differences, similar to blood group differences, exist in tissues other than blood, and that a tumour arising in a given tissue preserves the allo-antigenic characteristics of its host. He further correctly speculated that the allo-antigens induce an immune response in a new host lacking them.

This was the discovery of the histocompatibility system, which is essential for defence against virus infection, prevents allo-transplantation [63] and influences the risk of autoimmune disease, as described below.

\section{Human Leukocyte Antigens (HLA)}

Unlike the blood group antigens, A, B, O, on red blood cells, important for blood transfusions, the histocompatibility antigens are on the surface of all nucleated cells, including the white cells, the leukocytes, where they were discovered and named by Dausset and Svejgard the Human Leukocyte Antigens (HLA) [64]. The genes for the HLA antigens are in the Major Histocompatibilty Complex (MHC), situated on the short arm of chromosome 6 in man and on chromosome 17 in the mouse [65].

\section{Functions of the major histocompatibility complex}

As shown in Table 3, the prime role of our histocompatibility systems is to keep us alive in the face of the speed with which infecting viruses replicate. Our bodies mistake foreign transplants as dangerous virus infection of our tissues [66]. A monumental advance was made by Zinkernagel and Doherty [67] who discovered that cells infected by a virus extrude a peptide from the virus on to the histocompatibility antigens on their cell surface, where it is exposed to the powerful cytotoxic $\mathrm{T}$ cell clones, continually policing our histocompatibility antigens for evidence of change indicative of virus infection.

\begin{tabular}{|c|c|c|c|}
\hline \multicolumn{4}{|c|}{ 1. The race between virus and cytotoxic $T$ cell. } \\
\hline The contestants & Replication time & \multicolumn{2}{|l|}{ Progeny } \\
\hline Influenza virus & 10 hours [68] & \multicolumn{2}{|l|}{1,000 virions } \\
\hline Cytotoxic T cell & 18 hours & \multicolumn{2}{|l|}{2 T cells } \\
\hline The race & Virions & T cells & Virion/T cell ratio \\
\hline Day 1 & 1 & $10^{6}$ & $1 / 10^{6}$ \\
\hline Day 2 & $1 \times 1,000^{2.4}$ & $10^{6} \times 2^{1.3}$ & $6 / 1$ \\
\hline Day 3 & $2.5 \times 10^{14}$ & $6.3 \times 10^{6}$ & $10^{7} / 1$ \\
\hline Day 4 & $4 \times 10^{21}$ & $1.6 \times 10^{7}$ & $10^{14} / 1$ \\
\hline \multicolumn{4}{|c|}{ The result: the virus wins, the patient dies. } \\
\hline \multicolumn{4}{|c|}{$\begin{array}{l}\text { 2. Consequences of the explosive speed of viral replication. } \\
\text { Hence, cytotoxic T cell clones need to be } \\
\text { 1. Large, preformed (no time for expansion). } \\
\text { 2. Specific for conjoint virus-MHC antigenic target, so as not to be muffled by the } \\
\text { myriad numbers of free virions. This explains, }\end{array}$} \\
\hline \multicolumn{4}{|c|}{ 1. Why allografts are rejected. } \\
\hline \multicolumn{4}{|c|}{ 2. The strength of allograft rejection, Simonsen phenomenon [69]. } \\
\hline \multicolumn{4}{|c|}{$\begin{array}{l}\text { 3. The need for the MHC restriction phenomenon discovered by Zinkernagel } \\
\text { and Doherty [67], the presentation of viral antigens to cytotoxic } \mathrm{T} \text { cells on host } \\
\text { histocompatibility antigens, so that the anti-viral immune attack is directed at the } \\
\text { virus-infected cells, the virus factories. }\end{array}$} \\
\hline
\end{tabular}

Table 3: The Histocompatibility System exists to enable host survival of virus infection [66].

After Vladutiu and Rose [70] discovered that histocompatibility antigens influence the risk of autoimmune disease in mice, world-wide studies found weak 2-5 fold associations between various autoimmune diseases and specific HLA antigens, but in 1973
Schlosstein and Terasaki [71] found a 69-fold association between ankylosing spondylitis and the HLA antigen B27. This galvanised the medical world, setting up numerous research studies, well summarized by Tiwari and Terasaki in their comprehensive 1985 review of HLA and disease associations [72].

\section{Solution of the genetics of autoimmune disease}

The Bielschowskys' discovery of autoimmune haemolytic anaemia in their New Zealand Black (NZB) inbred strain of mice [73] led to the further discovery by Howie and Helyer [74] of lupus nephritis in (NZB x NZW) F1 mice. Realising that this autoimmune kidney disease, not present in either parent, must be caused by at least one gene from each parental strain, Knight and Adams made backcross and linkage studies, finding three genes for lupus nephritis [75], one from the NZB mice and two from the NZW mice. This has been confirmed and extended by Drake et al., [76] and Kono et al., [77], using the wonderfully detailed microsatellite gene markers. In a similar study of the autoimmune anaemia of the NZB mice, using crosses with the NZC strain, a gene necessary for production of the anti-erythrocyte autoantibodies was found to be distantly linked to the black-brown coat colour gene on chromosome 4. In all Knight and Adams found four genes with linkage information coding for autoimmune disease in mice [78]. None were the expected V genes, one was in the MHC and two appeared to be in the neighbourhood of the minor histocompatibility antigens, $\mathrm{Hh}$ and $\mathrm{H}-18$.

\section{The H Gene Theory}

This example of what Einstein [79] called a "stumble right up against the thing", enabled Adams and Knight to link the fields of transplantation genetics [63], immunology and autoimmunity, to arrive at the $\mathrm{H}$ Gene Theory.

This states that histocompatibility antigen genes, major, minor and HY (the male sex antigen), together with the $\mathrm{V}$ (Variable region) genes coding for antigen receptors on $\mathrm{B}$ and $\mathrm{T}$ lymphocytes, are the germ-line immune response genes, the genes that influence the risk of autoimmune disease [80,81].

\section{Microbial Triggers}

Autoimmune diseases are caused by malfunction of the immunity system, being consequences of infection by bacteria or viruses [82].

Rheumatic carditis and Streptococci: Before the advent of penicillin, rheumatic fever, with crippling or fatal lesions of the heart, was a frequent consequence of infection by $\beta$-haemolytic streptococci of Lancefield Group A. This was because of an antigenic similarity between a component of these streptococci and heart tissue, discovered by Kaplan and Meyeserian [83]. Today, with such infection therapeutically aborted by penicillin, rheumatic heart disease, once common, has become rare.

Glomerulonephritis and Streptococci: Post-infective glomerulonephritis follows infection by Group A streptococci of multiple M types. This disease is also less frequent due to use of antibiotics.

\section{Reactive arthritis}

This has been observed after enteric infection with Shigella, Salmonella, Yersinia, Compylobacter and genital infection with Neisseria gonorrhea.

Rheumatoid Arthritis (RA) and Proteus mirabilis [84]: Multiple studies over three decades have found high titres of antibodies against 
this bacterium in a total of 1375 RA patients, but not in other diseases or healthy controls in studies by independent groups in 15 different countries. There was no such elevation in antibodies against 27 other microbial agents. There is evidence that the upper urinary tract is the main site of Proteus infection in RA.

In brilliant studies, inventing diverse biochemical and other technology, Wilson and other members of Ebringer's team showed shared amino acid sequences between major histocompatibility Class II glycoproteins, type XI collagen and Proteus mirabilis in rheumatoid arthritis [84]. This shows in detail how Proteus mirabilis triggers the autoimmune attack on the joint collagen of patients with HLA-DR1/4.

Ankylosing Spondylitis (AS) and Klebsiella: In world-wide studies involving 1330 AS patients and 1191 healthy controls, the AS patients showed significantly increased antibody titres to Klebsiella. There is evidence that the gut is the main site of Klebsiella infection in AS.

Schizophrenia and virus infection: Acute schizophrenia has been observed to follow upper respiratory tract virus infection and John Knight has assembled much evidence that schizophrenia is an autoimmune disease caused by autoantibodies that react with neuronal receptors influencing the limbic system of the brain $[47,86]$.

Recently, Fabienne Brilot [87], a Paediatrician, studying post-infectious encephalomyelitis in children, suspecting an autoimmune basis, developed a new method of detecting antibodies to cell surface dopamine-2 receptors. It would be of great interest to test blood from acute schizophrenics with this method, to see if it contains the autoantibodies that cause schizophrenia.

Seeking antigenic triggers and their corresponding autoantigen, with excellent technology at the NIH, Laing et al., [88] immunized rabbits with neurotropic strains of influenza virus, inducing autoantibodies to a brain-specific $37-\mathrm{kDa}$ protein. This needs further exploration, as does the whole field of psychotic aetiology, until the presumptive forbidden clones have been demonstrated with the clarity obtained for Graves' diseases and myasthenia gravis.

\section{Information from Sequencing Antigens on Triggering Bacteria}

Ebringer's Basic Books: Details of the development of the methods used for successful determination of the amino acid sequences of antigens on the rheumatoid arthritis-triggering bacteria, Proteus mirabilis are described in the book, "Rheumatoid arthritis and Proteus" by Ebringer [89] Figure 7. Similarly, the book "Ankylosing spondylitis and Klebsiella", also by Ebringer [90], describes how the amino acid sequences of antigens on Klebsiella pneumoniae, that enormously increase the risk of ankylosing spondylitis, were determined, and how they exert their effect.

Discovered that Proteus mirabilis in the upper urinary tract triggers rheumatoid arthritis.

Discovered that Klebsiella pneumoniae in the gut triggers ankylosing spondylitis.

Confirmed the H Gene Theory by finding two antigens on Proteus, one resembling HLA-DR1/4 the predisposing HLA antigen, one resembling the autoantigen attacked.

Showed how HLA-B27 predisposes, 69-fold, to ankylosing spondylitis.

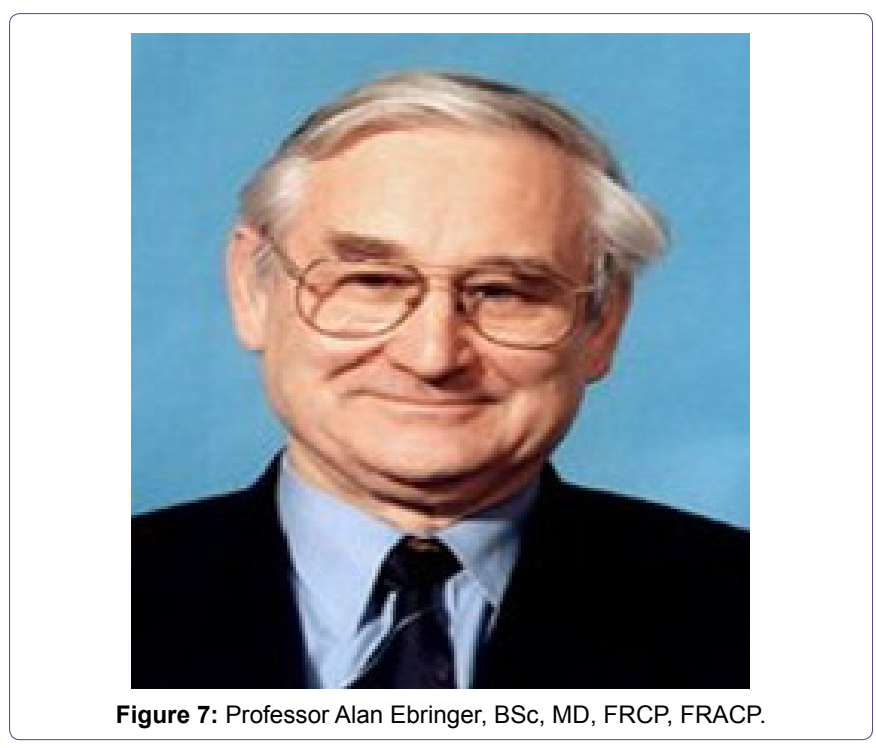

Confirmation of the $\mathbf{H}$ Gene theory: This research provides experimental confirmation, at the molecular level, of the $\mathrm{H}$ Gene Theory of the inheritance of the autoimmune diseases, described above, in confirming the speculated presence of multiple antigens on triggering bacteria and alternative clonal development enabling development of the forbidden clones that cause the associated autoimmune diseases.

How HLA-DR1/4 predisposes to rheumatoid arthritis [44]: Figure 5 shows space-filling models of the amino acid sequences of the histocompatibility antigen HLA-DR1/4 and the Proteus mirabilis haemolysin antigen. Close structural similarity is apparent. This means the immune tolerance imposed by the histocompatibility antigen will extend to this Proteus antigen, preventing immune reaction with it.
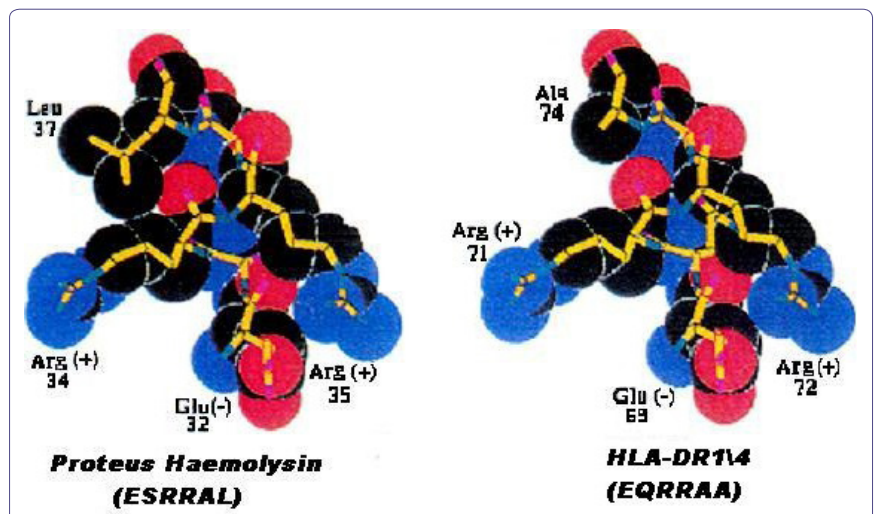

Figure 8: Molecular similarity between histocompatibility antigen HLA-DR1/4 and Proteus haemolysin, preventing immune reaction against this bacterial antigen [89].

Figure 9 shows space-filling models of the amino acid sequences of the Proteus mirabilis urease antigen and Type 11 collagen, an autoantigen attacked in rheumatoid arthritis. The urease antigen is completely different from HLA-DR1-4, so will not be protected from immune reaction, being free to stimulate development of a forbidden clone reacting with the closely similar Type 11 collagen molecule, an autoantigen attacked in rheumatoid arthritis. 


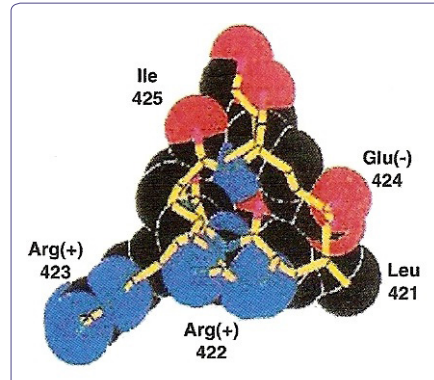

$\alpha-2(X I)$ collagen (LRREI)

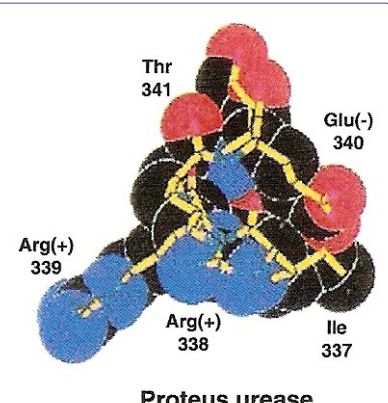

Proteus urease (IRRET)
Figure 9: Molecular similarity of Proteus urease and Type $X I$ collagen an autoantigen attacked in rheumatoid arthritis. This explains how infection with Proteus mirabilis causes rheumatoid arthritis [89].

How HLA-B27 predisposes to ankylosing spondylitis [44]: Figure 10 shows space-filling models of the amino acid sequences of the histocompatibility antigen HLA-B27 and two antigenic peptides on the bacterium Klebsiella pneumoniae. The Klebsiella nitrogenase antigen closely resembles HLA-B27, so will be covered by the tolerance induced by HLA-B27, but the bacterium's pullanase peptide is different and able to stimulate development of a forbidden clone attacking the spine to cause ankylosing spondylitis.

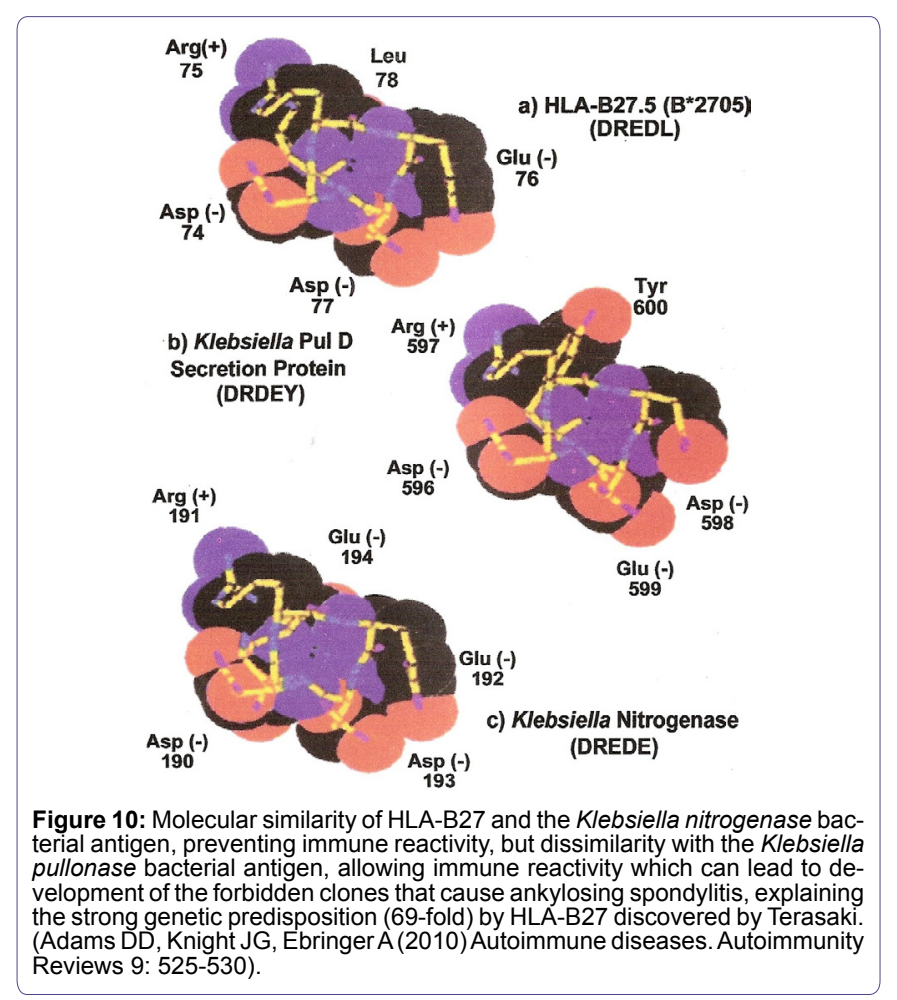

\section{Prophylaxis of Autoimmune Diseases}

The poliomyelitis virus epidemics: A New Zealand example occurred in 1938, reported in the press and observed by Adams trapped in a boarding school in Masterton. An epidemic of leg paralyses occurred in Christchurch and spread progressively north, from town to town, to Picton, Wellington, Featherston, then Carterton, the town next to Masterton, engendering great fear. Then the boy in the bed next to Adams complained of a stiff neck, was taken away and reported to have polio. Six months later he returned with a paralysed leg. Adams and his schoolmates were all unaffected.

\section{Paralysis a rare autoimmune complication of universal virus infection?}

I postulate that the leg paralyses of poliomyelitis were a rare autoimmune complication of virtually universal virus infection, the paralyses probably caused by forbidden clones of cytotoxic $\mathrm{T}$ cells which attacked anterior horn neurons in the spine, hence the Pathologists' appropriate name, "acute anterior poliomyelitis."

The Salk (killed) and Sabin (attenuated) polio vaccines have been brilliantly successful in preventing the polio leg paralyses. This exemplifies how autoimmune diseases in general, can be prevented by finding and vaccinating against their microbial triggers.

The lead in prophylaxis given by the polio vaccines: The Salk (killed) and Sabin (attenuated) polio vaccines have been brilliantly successful in preventing the polio leg paralyses. This exemplifies how autoimmune diseases in general, can be prevented by finding and vaccinating against their microbial triggers.

Finding microbial triggers: Ebringer has succeeded in this with rheumatoid arthritis and ankylosing spondylitis. He has pioneered this new field of medical research, developing a whole new technology that needs to be copied in other diseases, especially schizophrenia. Systematic studies of autoimmune diseases, with collaboration between clinicians and microbiologists are needed.

Prevention of ankylosing spondylitis: There is 69 -fold increased risk of ankylosing spondylitis in males with HLA-B27 [71]. Ebringer's discovery that the bacterium Klebsiella pneumoniae triggers ankylosing spondylitis offers prevention of this disease by vaccination of HLA-B27 positive boys with Klebsiella pneumoniae. This could initiate a new form of prophylaxis, which could culminate in prevention of schizophrenia, once its triggering microbe (probably viral) has been identified.

\section{Discussion}

Some disease associations are cross-tissue autoimmunity, for example the eye proptosis of Graves' disease, caused by variants of the thyroid-stimulating autoantibodies that react with receptors on orbital fat cells [30], and diabetic retinopathy [21], probably caused by destruction of retinal pericyte cells by antigenic variants of the $\mathrm{T}$ cell forbidden clones that destroy the pancreatic islet $\beta$ cells to cause Type 1 diabetes.

Many autoimmune diseases, such as Graves' disease, already have satisfactory therapy. Immunotherapy, by radiological or chemical immune ablation, with immune reconstitution by autologous bone marrow cells, pioneered by Tyndall [91], can be used to save the lives of patients with dangerous autoimmune diseases, such as systemic scleroderma [92].

Selective destruction of forbidden clones could be achieved by isolating their autoantigen (such as the TSH receptor of Graves' disease, cloned by Vassart and Dumont) [93] and attaching it to a cytotoxic moiety, such as bungarotoxin or ${ }^{131} \mathrm{I}$ iodine (emitting short-range $\beta$ particles), then administering the molecular complex intravenously to destroy the pathogenic clones of plasma cells. When monoclonal antibody technology was discovered, it was mistakenly assumed that this would provide cures for the autoimmune diseases, a notion greatly encouraged by the drug companies. Struggling to help his patients get benefit from use of Rituximab, Dreyfus [94] envisages major progress from anti-viral therapies and ultimately virus vaccines. 
Prevention is better than cure, so finding and countering antigenic triggers of autoimmune diseases is the ideal. Recognition of the universality of microbial triggers of autoimmune diseases is a major advance, in showing how the diseases can be prevented by finding and vaccinating against their triggers. Ebringer has led the way by discovering three triggers and developing the technology for finding others.

\section{References}

1. Dubois RJ (1951) Louis Pasteur. Gollancz, London.

2. Whitbury L, Hynes M (1953) Medical Bacteriology. Churchill, London.

3. Baron S (1996) Medical Microbiology. (4th edn), University of Texas, Galveston, USA.

4. Paul WE (1999) Fundamental Immunology. (4th edn), Lippincott-Raven, Philadelphia, USA.

5. Watson JD, Crick FH (1953) Molecular structure of nucleic acids; a structure for deoxyribose nucleic acid. Nature 171: 737-738.

6. Watson JD, Crick FH (1953) Genetical implications of the structure of deoxyribonucleic acid. Nature 171: 964-967.

7. Jerne NK (1955) The natural-selection theory of antibody formation. Proc Natl Acad Sci USA 41: 849-857.

8. Burnet FM (1959) The clonal selection theory of acquired immunity. Cambridge University Press, London.

9. Dameshek W, Schwartz SO (1938) Haemolysins as cause of chemical and experimental haemolytic anaemias, with particular reference to nature of spherocytosis and increased fragility. Amer J Med Sci 196: 769

10. Freund J, Lipton MM, Thompson GE (1953) Aspermatogenesis in the guinea pig induced by testicular tissue and adjuvants. J Exp Med 97: 711-726.

11. Adams DD, Purves HD (1956) Abnormal responses in the assay of thyrotrophin. Proc Univ Otago Med School 34: 11-12.

12. Witebsky E, Rose N, Terplan K, Paine JR, Egan RW (1957) Chronic thyroiditis and autoimmunisation. JAMA 164: 1439-1447.

13. Doniach D, Roitt IM (1957) Auto-immunity in Hashimoto's disease and its implications. J Clin Endocrinol Metab 17: 1293-1304.

14. Porter RR (1959) The hydrolysis of rabbit y-globulin and antibodies with crystalline papain. Biochem J 73: 119-126.

15. Burnet M (1959) Auto-immune disease. I. Modern immunological concepts. Br Med J 2: 645-650

16. Knight J, Laing P, Knight A, Adams D, Ling N (1986) Thyroid-stimulating autoantibodies in individual patients contain only one type of light chain, showing origin from mutation in a single lymphocyte. J Clin Endocrinol Metab 62: 342-347.

17. Knight A, Adams DD (1983) Absence of allotypic variation in the autoantigen for thyroid stimulating autoantibodies. Clin Exp Immunol 52: 317-324.

18. Ben-Nun A, Wekerle $H$, Cohen IR (1981) The rapid isolation of clonable antigen-specific $T$ lymphocyte lines capable of mediating autoimmune encephalomyelitis. Eur J Immunol 11: 195-199.

19. Cheynier R, Henrichwark S, Wain-Hobson S (1998) Somatic hypermutation of the $T$ cell receptor $V$ beta gene in microdissected splenic white pulps from HIV-1-positive patients. Eur J Immunol 28: 1604-1610.

20. Sherwin RS (2000) Diabetes mellitus. In: Goldman L, Bennett JC (eds.). Text book of Medicine. (21st edn). Saunders, Philadelphia. Pg: 1893-1898.

21. Adams DD (2008) Autoimmune destruction of pericytes as the cause of diabetic retinopathy. Clin Ophthalmol 2: 295-298.

22. McKenzie JM (1958) Delayed thyroid response to serum from thyrotoxic patients. Endocrinology 62: 865-868.
23. Knight A, Cague WS, Adams DD (1980) Measurements of the thyroid-stimulating autoantibodies. In: Rose NR, Friedman $\mathrm{H}$ (eds.). Manual of Clinica Immunology. (2nd edn). American Society for Microbiology, Washington. Pg: 391-402.

24. Kriss JP, Pleshakov V, Chien JR (1964) Isolation and identification of the long-acting thyroid stimulator and its relation to hyperthyroidism and circumscribed pretibial myxedema. J Clin Endocrinol Metab 24: 1005-1028.

25. Adams DD, Kennedy TH (1967) Occurrence in thyrotoxicosis of a gamma globulin which protects LATS from neutralization by an extract of thyroid gland. J Clin Endocrinol Metab 27: 173-177.

26. Adams DD, Kennedy TH (1971) Evidence to suggest that LATS protector stimulates the human thyroid gland. J Clin Endocrinol Metab 33: 47-51.

27. Adams DD, Fastier FN, Howie JB, Kennedy TH, Kilpatrick JA, et al. (1974) Stimulation of the human thyroid by infusions of plasma containing LATS protector. J Clin Endocrinol Metab 39: 826-832.

28. Adams DD, Kennedy TH, Stewart RD (1974) Correlation between long-acting thyroid stimulator protector level and thyroid ${ }^{131}$ I uptake in thyrotoxicosis. $\mathrm{Br}$ Med J 2: 199-201.

29. Adams DD, Knight A, Knight JG, Laing P (1987) Graves' disease: a paradigm for autoimmunity. In: Pinchera A, Ingbar SH, McKenzie JM, Fenzi GF (eds.). Thyroid Autoimmunity. Plenum, New York. Pg: 1-10.

30. Rundle F, Pochin E (1944) The orbital tissues in thyrotoxicosis: a quantitative analysis relating to exophthalmos. Clin Sci 5: 51-74.

31. Munro DS, Dirmikis SM, Humphries H, Smith T, Broadhead GD (1978) The role of thyroid stimulating immunoglobulins of Graves's disease in neonatal thyrotoxicosis. Br J Obstet Gynaecol 85: 837-843.

32. Adams DD (1983) Autoimmune Mechanisms. In: TF Davies (ed.). Autoimmune Endocrine Disease. John Wiley \& Sons, New York. Pg: 1-39.

33. Mitchison NA (1954) Passive transfer of transplantation immunity. Proc R Soc Lond B Biol Sci 142: 72-87.

34. Sutherland DE, Goetz FC, Sibley RK (1989) Recurrence of disease in pancreas transplants. Diabetes 1: 85-87.

35. Klintworth GK (1988) The eye. In: Rubin E, Farber JL (eds.). Pathology. (2nd edn). Lippincott, Philadelphia. Pg: 1456-1483

36. Lindstrom J, Shelton D, Fujii Y (1988) Myasthenia gravis. Adv Immunol 42 : 233-284.

37. Saus J, Wieslander CM, Langerveld JPM, Qinones S, Hudson BG (1988) Identification of the Goodpasture antigen as the alpha 3 (IV) chain of collagen IV. J Biol Chem 1988; 263: 13374-13380.

38. Roitt IM, Doniach D, Shapland C (1965) Autoimmune phenomena in relation to gastric mucosa in human disease. In: Grabar P, Miescher PA (eds.). Immunopathology. IV International Symposium. Schwabe, Basel. Pg: 314-324.

39. Adams DD (1982) Systemic lupus erythaematosus: a simple concept of the pathogenesis and its genetic basis. In: Dawkins RL, Christiansen FT, Zilko $\mathrm{PJ}$ (eds.). Immunogenetics in rheumatology. Amsterdam: Excerpta Medica. Pg: 242-243

40. Exner T (1989) Lupus anticoagulant. Today's Life Sciences. 1: 40-46.

41. Boey ML, Colaco CB, Gharavi AE, Elkon KB, Loizou S, et al. (1983) Thrombosis in systemic lupus erythematosus: striking association with the presence of circulating lupus anticoagulant. Br Med J (Clin Res Ed) 287: 1021-1023.

42. Davis AE 3rd, Ziegler JB, Gelfand EW, Rosen FS, Alper CA (1977) Heterogeneity of nephritic factor and its identification as an immunoglobulin. Proc Natl Acad Sci USA 74: 3980-3983.

43. Kaplan ME (1985) Autoimmune haemolytic disease due to warm-reacting antibodies. In: Wyngaarden JB, Smith LM (eds.). Textbook of Medicine. (17th edn), Saunders, Philadelphia. Pg: 908-910. 
44. Wilson C, Ebringer A, Ahmadi K, Wrigglesworth J, Tiwana H, et al. (1995) Shared amino acid sequences between major histocompatibility complex Class II glycoproteins, type XI collagen and proteus mirabilis in rheumatoid arthritis. Ann Rheum Dis 54: 216-220.

45. Ménard HA, el-Amine M (1996) The calpain-calpastatin system in rheumatoid arthritis. Immunol Today 17: 545-547.

46. Knight JG (1982) Dopamine-receptor-stimulating autoantibodies: a possible cause of schizophrenia. Lancet 2: 1073-1076.

47. Knight JG, Knight A, Pert CB (1987) Is schizophrenia a virally-triggered anti-receptor autoimmune disease? In: Helmchen $\mathrm{H}$, Henn FA (eds.). Biological perspectives of schizophrenia. Wiley, New York. Pg: 107-127.

48. Potter SR, Bienenstock J, Goldstein S, Buchanan WW (1985) Fibroblas growth factors in scleroderma. J Rheumatol 12: 1129-1135.

49. Xu WD, Leroy EC, Smith EA (1991) Fibronectin release by systemic sclerosis and normal dermal fibroblasts in response to TGF-beta. J Rheumato 18: $241-246$

50. Gilliland BC (2001) Systemic sclerosis. In: Braunwald E, Fauci AS, Kasper DL, Hauser S, Longo D, et al. (eds.). Harrison's Principles of Internal Medicine. (15th edn), McGraw-Hill, New York, USA. Pg: 1937-1946.

51. Fallon MD, Schwamm HA (1989) Paget's disease of bone. An update on the pathogenesis, pathophysiology, and treatment of osteitis deformans. Pathol Annu 24 Pt 1: 115-159.

52. Ebringer A (2013) Ankylosing spondylitis and Klebsiella. Springer, London.

53. Williams DG, Peters DK (1987) Glomerulonephritis and renal manifestations of systemic disease. In: Weatheral DJ, Ledingham JGG, Warrell DA (eds.) Oxford Textbook of Medicine. (2nd edn), University Press, Oxford, USA. Pg 36-55

54. Bisno AL (1985) Rheumatic fever. In: Wyngaarden JB, Smith LM (eds.). Textbook of Medicine. (17th edn), Saunders, Philadelphia. Pg: 1527-1533.

55. Tagg JR, McGiven AR, Guthrie DA (1972) Heart-reactive antibodies in rheumatic fever. Med J Aust 1: 621-624.

56. Dienstag JL, Isselbacher KJ (2001) Autoimmune hepatitis. In: Braunwald E Fauci AS, Kasper DL, Hauser SL, Longo DL, et al. (eds.). Harrison's Principles of Internal Medicine. (15th edn), McGraw-Hill, New York, USA. Pg 1750-1752.

57. Williams GH, Dluhy RG (2001) Disorders of the adrenal cortex. In: Braunwald E, Fauci AS, Kasper DL, Hauser SL, Longo DL, et al. (eds.). Harrison's Principles of Internal Medicine. (15th edn), McGraw-Hill, New York, USA. Pg: 2084-2105.

58. Rubin E, Faber J (1994) Primary biliary cirrhosis. In: Rubin E, Farber JL (eds.). Pathology. (2nd edn), Lippincott, Philadelphia. Pg: 740-743.

59. Hauser SL, Goodkin GE (2001) Multiple sclerosis and other demyelinating diseases. In: Braunwald E, Fauci AS, Kasper DL, Hauser SL, Longo DL, et al. (eds.). Harrison's Principles of Internal Medicine. (15th ed), McGraw-Hill, New York, USA. Pg: 2452-2461.

60. Banker BQ, Engel AG (1986) The polymyositis and dermatomyositis syndromes. In: Engel AC, Banker BQ (eds.). Myology: basic and clinical. McGraw Hill, New York, USA. Pg: 1385-1422.

61. Klein J (1975) Biology of the mouse histocompatibility-2 complex. Berlin, Springer.

62. Haldane JBS (1933) The genetics of cancer. Nature 132: 266-267.

63. Auchinloss H, Sykes M, Sacks DH (1999) Transplant Immunology. In: Fundamental Immunology. (4th edn), Lippincott-Raven, Philadelphia, USA

64. Dausset J, Svejgaard A (1977) HLA and disease. Munksgaard, Copenhagen, USA.

65. McKusick VA (1978) Mendelian inheritance in man. Catalogs of autosoma dominant, autosomal recessive and X-linked phenotypes (5th edn). Johns Hopkins University Press, Baltimore, USA
66. Adams DD (1987) Protection from autoimmune disease as the third function of the major histocompatibility gene complex. Lancet 2: 245-249.

67. Zinkernagel RM, Doherty PC (1974) Restriction of in vitro T cell-mediated cytotoxicity in lymphocytic choriomeningitis within a syngeneic or semiallogeneic system. Nature 248: 701-702.

68. Fenner F, White DO (1975) Medical Virology. Academic Press, London, UK. Pg: 75.

69. Simonsen M (1969) On the nature and measurement of antigenic strength Transplant Rev 3: 22-35.

70. Vladutiu AO, Rose NR (1971) Autoimmune murine thyroiditis relation to Histocompatibility (H-2) type. Science 174: 1137-1139.

71. Schlosstein L, Terasaki PI, Bluestone R, Pearson CM (1973) High association of an HL-A antigen, W27, with ankylosing spondylitis. N Engl J Med 288 704-706.

72. Tiwari JL, Terasaki PI (1985) HLA and disease associations. Springer, New York, USA.

73. Bielschowsky M, Helyer BJ, Howie JB (1959) Spontaneous haemolytic anaemia in mice of the NZB/BL strain. Proc Univ Otago Med Sch 37: 9-11.

74. Howie JB, Helyer BJ (1968) The immunology and pathology of NZB mice. Adv Immunol 9: 215-266.

75. Knight JG, Adams DD (1978) Three genes for lupus nephritis in NZB x NZW mice. J Exp Med 147: 1653-1660.

76. Drake CG, Babcock SK, Palmer E, Kotzin BL (1994) Genetic analysis of the NZB contribution to lupus-like autoimmune disease in (NZB x NZW) F1 mice. Proc Natl Acad Sci USA 91: 4062-4066.

77. Kono DH, Burlingame RW, Owen DG, et al. (1994) Lupus susceptibility loci in New Zealand mice. Proc Natl Acad Sci USA 91: 10,168-10,172.

78. Knight JG, Adams DD (1981) Genes determining autoimmune disease in New Zealand mice. J Clin Lab Immunol 5: 165-170.

79. Einstein A (1934) Essays in science. Philosophical Library Inc, New York. Pg: 92.

80. Adams DD, Knight JG (1980) H gene theory of inherited autoimmune dis ease. Lancet 1: 396-398.

81. Knight JG, Adams DD (1982) The genetic basis of autoimmune disease. Ciba Found Symp : 35-56.

82. Shevack EM (1998) Organ-specific autoimmunity. In: WE Paul (ed). Fundamental Immunology. (4th edn), Lippincott-Raven, New York. Pg: 1089-1125.

83. Kaplan MH, Meyeserian M (1962) An immunological cross-reaction between group-A streptococcal cells and human heart tissue. Lancet 1: 706-710.

84. Rashid T, Ebringer A (2007) Rheumatoid arthritis is linked to Proteus--the evidence. Clin Rheumatol 26: 1036-1043.

85. Ebringer A, Rashid T, Wilson C, Ptaszynska T, Fielder M (2006) Ankylosing spondylitis, HLA-B27, and Klebsiella pneumoniae - an overview proposed fo early diagnosis and treatment. Curr Rheumatol Rev 2: 55-68.

86. Knight JG (1982) Dopamine-receptor-stimulating autoantibodies: a possible cause of schizophrenia. Lancet 2: 1073-1076.

87. Dale RC, Merheb V, Pillai S, Wang D, Cantrill L, et al. (2012) Antibodies to surface dopamine-2 receptor in autoimmune movement and psychiatric disorders. Brain 135: 3453-3468.

88. Laing P, Knight JG, Hill JM, Harris AG, Oxford JS, et al. (1989) Influenza viruses induce autoantibodies to a brain-specific 37-kDa protein in rabbit. Proc Natl Acad Sci U S A 86: 1998-2002.

89. Ebringer A (2012) Rheumatoid arthritis and Proteus. Springer, London.

90. Ebringer A (2013) Ankylosing Spondylitis and Klebsiella. Springer, London. 
91. Farge D, Passweg J, van Laar JM, Marjanovic Z, Besenthal C, et al. (2004) Autologous stem cell transplantation in the treatment of systemic sclerosis: report from the EBMT/EULAR Registry. Ann Rheum Dis 63: 974-981.

92. Englert H, Katelaris C, McGill N, Schrieber L, Moore J (2005) 'Grape-sultana' sign represents a favourable response to aggressive treatment of early diffuse systemic scleroderma. Intern Med J 35: 436-437.
93. Costagliola S, Morgenthaler NG, Hoermann R, Badenhoop K, Struck J, et al. (1999) Second generation assay for thyrotropin receptor antibodies has superior diagnostic sensitivity for Graves' disease. J Clin Endocrinol Metab 84: 90-97.

94. Dreyfus DH (2011) Autoimmune disease: A role for new anti-viral therapies? Autoimmun Rev 11: 88-97. 